\title{
A cardiogen sokk modellezése pericardialis tamponáddal
}

\section{Experimental model for cardiogenic shock with pericardial tamponade}

\author{
BARI GÁBOR ${ }^{1}$, SZÜCS SZILÁRD², ÉRCES DÁNIEL ${ }^{2}$, UGOCSAI MELINDA $^{2}$, BOZSÓ NOÉMI ${ }^{2}$, \\ BALOG DÓRA², BOROS MIHÁLY², VARGA GABRIELLA ${ }^{2, @ ~}$
}

\author{
Szegedi Tudományegyetem, Szeged \\ ${ }^{1}$ II. Belgyógyászati Klinika és Kardiológiai Központ, Szívsebészeti Osztály \\ (osztályvezető: Dr. Bogáts Gábor) \\ ${ }^{2}$ Sebészeti Mütéttani Intézet (igazgató: Dr. Boros Mihály)
}

\begin{abstract}
Bevezetés: A pericardialis tamponád az életet közvetlenül veszélyeztető, alacsony perctérfogatú kórállapot, amelynek keringési következményei minden szövet, köztük a vese és a bélnyálkahártya mikrokeringését is súlyosan érintik. Célkitüzés: Kísérletünk célja a pericardialis tamponád klinikai képének modellezésére alkalmas, hemodinamikailag stabil, kontrollálható állatmodell kifejlesztése volt. Módszerek: Altatott vietnami törpesertések két csoportjában laparotomiát követően a szívburokba a rekeszen keresztül, thoracotomia nélkül kanült helyeztünk. Az első, álmütött csoport kontrollként szolgált $(n=6)$, a második csoportban a pericardium saját vérrel való feltöltésével 60 perces tamponádot hoztunk létre $(n=6)$. Monitoroztuk a tamponád és az azt követő 180 perces reperfúzió alatt a makrohemodinamikát és a vékonybél mikrohemodinamikai változásait. Vizsgáltuk a fehérvérsejt-akkumulációt jelző mieloperoxidáz (MPO) -enzimaktivitást és pásztázó lézeres endomikroszkóppal a vékonybél in vivo szövettani elváltozásait. Eredmények: A tamponád következtében megemelkedett a centrális vénás nyomás és a szívfrekvencia, lecsökkent az artériás középnyomás, az arteria mesenterica superior $(355,5 \pm 112,4 v s .182,0 \pm 59,1 \mathrm{ml} / \mathrm{min})$ és az arteria renalis $(159,63 \pm 50,7 v s .35,902 \pm 27,9$ $\mathrm{ml} / \mathrm{min})$ áramlása, valamint az ileum mikrokeringése. Az MPO-aktivitás szignifikánsan megemelkedett $(3,66 \pm 1,6$ vs. $7,01 \pm 1,44 \mathrm{mU} / \mathrm{mg}$ fehérje) és romlott a vékonybél in vivo szövettani képe. Következtetések: Kísérleti modellünk alkalmas a szívtamponád jellegzetes keringési és biokémiai következményeinek vizsgálatára, reprodukálható, klinikailag releváns állatmodellnek tekinthető.
\end{abstract}

Kulcsszavak: pericardialis tamponád, állatmodell, cardiogen sokk, mesenterialis ischaemia

Introduction: Pericardial tamponade (PT) is a life-threatening condition, with low cardiac output. The hemodynamic consequences of PT can severely affect the circulation of all tissues, including the microcirculation of the kidneys and the intestinal mucosa. Our aim was to develop a hemodynamically stable and controllable large animal model of PT to study the consequences of cardiogenic shock. Methods: Two groups of anesthetized vietnamese minipigs ( $n=6$, both groups) were used. Following laparotomy, a cannula was fixed into the pericardium through the diaphragm without thoracotomy. A sham-operated group served as control, in the second group 60-min PT was induced by intrapericardial injection of heparinised own blood. Throughout PT and 180-min reperfusion, macrohemodynamics, renal circulation and mesenteric macro- and microcirculation were monitored. Myeloperoxidase (MPO) activity was measured and in vivo histology was performed by confocal laser scanning endomicroscopy. Results: The PT increased central venous pressure, heart rate and decreased mean arterial pressure, mesenteric flow (from $355.5 \pm 112.4 v \mathrm{~s} 182.0 \pm 59.1 \mathrm{ml} / \mathrm{min}$ ) and renal arterial flow (from $159.63 \pm 50.7$ vs $35.902 \pm 27.9 \mathrm{ml} / \mathrm{min}$ ) and the microcirculation of the ileum. Elevated MPO activity $(3.66 \pm 1.6$ vs $7.01 \pm 1.44 \mathrm{mU} / \mathrm{mg}$ protein) and injury of the ileal mucosa were present also. Summary: The reproducible large animal model is suitable for clinically relevant investigations of the hemodynamic and biochemical consequences of PT.

Keywords: pericardial tamponade, animal model, cardiogenic shock, mesenteric ischaemia

Beérkezett: 2017. június 19.; elfogadva: 2017. július 27.

Rövidítések: CLSEM = konfokális pásztázó lézeres endomikroszkóp; $\mathrm{CO}=$ perctérfogat; $\mathrm{CVP}=$ centrális vénás nyomás; $\mathrm{HR}$ = szívfrekvencia; $\mathrm{NCSP}=$ (non-cardiac surgical procedures) nem szívsebészeti invazív beavatkozások; $\mathrm{MAP}=$ artériás középnyomás; $\mathrm{MPO}=$ mieloperoxidáz; $\mathrm{NIH}=$ National Institutes of Health

\footnotetext{
${ }^{\circledR}$ Levelezési cím/Corr. address: Dr. Varga Gabriella, Szegedi Tudományegyetem, Sebészeti Műtéttani Intézet, 6720 Szeged, Szökefalvi-Nagy Béla u. 6. Telefon: +36 62545 103; Fax: +36 62545 743; E-mail: varga.gabriella.1@med.u-szeged.hu; gvarga36@gmail.com
} 


\section{Bevezetés}

Cardiogen sokk általában myocardialis infarctus után alakul ki, emellett szívsebészeti beavatkozásokat követően, valamint számos sürgősségi sebészi kórkép (például hasi aortaaneurysma-ruptura), úgynevezett nem szívsebészeti invazív beavatkozások (non-cardiac surgical procedures - NCSP), szeptikus, vérzéses sokk után, intra- vagy posztoperatív szövődményeként is jelentkezik. ${ }^{1}$ Cardiogen sokkot okozhat a szívsebészeti és invazív kardiológiai beavatkozások egyik legveszélyesebb szövődménye, a pericardialis tamponád is. A tamponád során a szívburokban leggyakrabban folyadék gyülemlik fel, amely lehet transsudatum vagy genny, de a klinikai gyakorlatban föleg a szívburokba történő vérzés okozhatja. ${ }^{2}$ A zárt szívburok megnövekedett nyomása miatt a vénás beáramlás gátlása alacsony verötérfogathoz, következményesen csökkent perctérfogathoz (CO) vezet, ami szöveti hypoxiát és többszervi károsodást okozhat. Lényeges, hogy a pericardialis tamponád hoszszabb távú szisztémás hatásai jelentősek lehetnek még abban az esetben is, ha a kiváltó ok megszünik és a magas pericardialis nyomást mütéti vagy egyéb intervenciós módon csökkentik. ${ }^{3}$ Ennek fö oka a sokk következtében kialakuló splanchnicus hipoperfúzió, amelynek során a szöveti ischaemia-reperfúzió gyulladásos reakcióhoz, bakteriális transzlokációhoz és szisztémás immunválaszhoz vezet. ${ }^{4}$

A humán kórképek mechanizmusainak és terápiáinak vizsgálatában az állatkísérletes modelleknek jelentős szerepük van, annak ellenére, hogy a laboratóriumi eredmények klinikai alkalmazhatósága gyakran korlátozott. Ennek fö oka a klinikai valóság és a modell közti eltérés, amit a minél pontosabb, megfelelően kialakított kísérletes elrendezéssel csökkenteni lehet. Érthető tehát, hogy jelentős az igény a modellek fejlesztésére és a limitációk csökkentésére, hogy az adott klinikai folyamatnak minél inkább megfelelő, az orvostudományban és az emberi gyógyászatban is alkalmazható eredményeket kapjunk. ${ }^{5}$

Jelen tanulmányunk célja az NCSP alatti kialakuló cardiogen sokk vizsgálatára és befolyásolására alkalmas, standardizálható kísérletes modell kialakítása volt, azzal a megkötéssel, hogy a keringésromlás időtartama, mértéke, jellegzetességei és következményei meghatározhatók legyenek. A korábbi tapasztalatok alapján a cardiogen sokk modellezése altatott, lélegeztetett nagyállaton kísérletes pericardialis tamponáddal megvalósítható, ha thoracotomiát követően egy pericardialis kanülön keresztül meghatározott ideig folyadékkal (kolloid oldattal) tölthetö fel a megnyitott pericardium. ${ }^{6}$ Ugyanakkor e modell hátránya maga a mellkasnyitás, amelynek során nagy sebfelszín keletkezik, a vérzés, a tüdősérülés veszélye és a kiterjedtebb szövetkárosodás mellett a tüdőfunkció romlásával és az egyre csökkenő ventiláció következményeivel is számolni kell. Mindezek alapján olyan mütéti tervet dolgoztunk ki a sebészeti és kardiológiai invazív intervenciókat kísérő cardiogen sokk modellezésére, ahol a thoracotomia elhagyható, és a kísérletes előnyök mellett a klinikai képhez való hasonlóság megtartható.

\section{Módszerek}

\section{Állatok}

Vizsgálatainkat a NIH (Guide for the Care and Use of Laboratory Animals) és az EU 2010/63 irányelveknek megfelelően a Szegedi Tudományegyetem Munkahelyi Állatkísérleti Bizottsága jóváhagyásával (engedélyszám: V/148/ 2013) altatott vietnami törpesertéseken végeztük $(n=12$, átlagos testtömeg $28 \pm 3 \mathrm{~kg}$ ), amelyeket a kísérletek előtt 12 óráig koplaltattunk.

\section{Mütéti beavatkozás}

Az altatás indukciója ketamin $(20 \mathrm{mg} / \mathrm{kg}$; CP-Ketamin 10\% injekció A.U.V. 25 ml; Produlab Pharma B.V, Raamsdonksveer, Hollandia) és xilazin ( $2 \mathrm{mg} / \mathrm{kg}$; CP-Xylazin 2\% injekció A.U.V 50 ml; Produlab Pharma B.V, Raamsdonksveer, Hollandia) kombinációjával, majd a fenntartás propofolinfúzióval $(6 \mathrm{mg} / \mathrm{ttkg} / \mathrm{h}$; Propofol $2 \% \mathrm{MCT} /$ LCT; Fresenius Kabi Deutschland GmbH, Bad Homburg, Németország) történt. Endotrachealis intubálást követően mesterséges lélegeztetést alkalmaztunk (Harvard Apparatus, South Natick, Massachusetts, Amerikai Egyesült Államok), amelynek során a légzési térfogatot $(9 \pm 2 \mathrm{ml} /$ ttkg), és a légzésszámot úgy állítottuk be, hogy a $\mathrm{PaCO}_{2}$ 35-45 Hgmm közé essen. Az állatokat a mütőasztalon háton fekvő helyzetben rögzítettük, melegítőmatraccal a testhőmérsékletüket normáltartományban $\left(36-37^{\circ} \mathrm{C}\right)$ tartottuk, és folyadékpótlás céljából Ringer laktát infúziót adtunk $10 \mathrm{ml} / \mathrm{ttkg} / \mathrm{h}$ volumensebességgel. Kipreparáltuk a bal vena jugularist, amelybe háromlumenes centrális vénás katétert

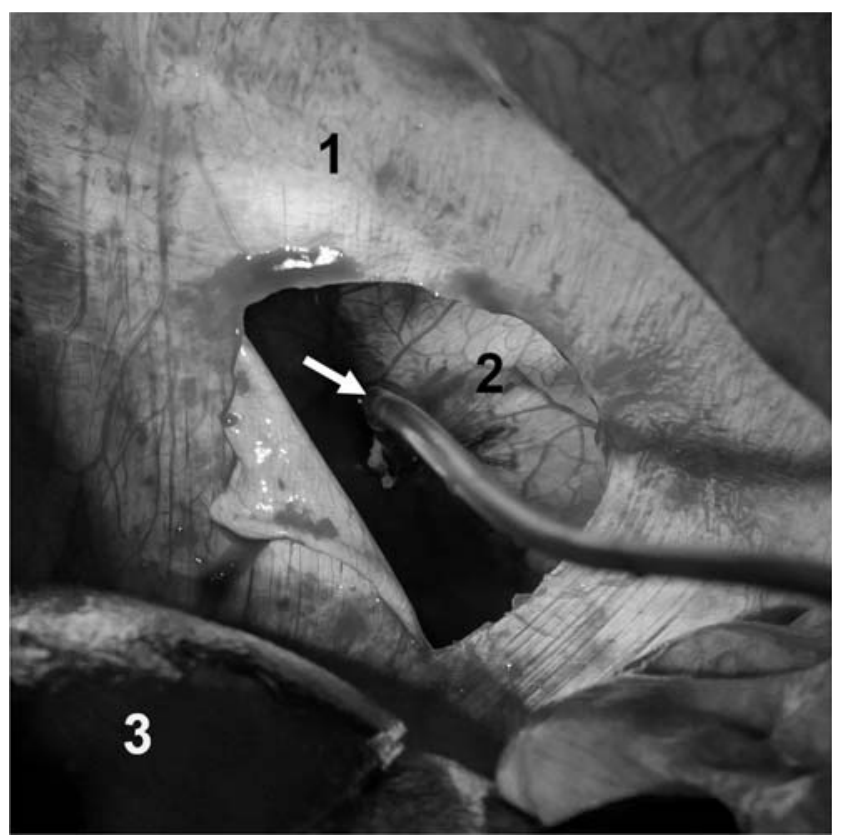

1. ábra. A pericardiumba transphrenicus úton történő kanülbehelyezéshez szükséges mütéti feltárás. A képen megjelölt képletek a diaphragma (1), a pericardium (2), a máj (3) és a pericardiumban rögzített kanül (nyíl) 
vezettünk (7 F; Edwards Lifesciences LLC, Irvine, Kalifornia, Amerikai Egyesült Államok), vénás nyomásmérés, vérmintavétel és infúzióbeadás céljából. A bal arteria femoralisba nyomásmérő katétert (PICCO Catheters; PULSION Medical Systems, Feldkirchen, Németország) helyeztünk invazív hemodinamikai monitorozás lehetőségének biztosítására. Median laparotomiát követően az arteria renalist és az arteria mesenterica superiort kipreparáltuk és köréjük egy-egy ultrahangos áramlásmérő fejet (Transonic Systems, Ithaca, New York, Amerikai Egyesült Államok) helyeztünk. Az állatok a kísérlet során folyamatos invazív hemodinamikai monitorozás alatt álltak, 30 percenként vérgázanalízist végeztünk. A rekeszen ejtett körülbelül $3 \mathrm{~cm}$-es metszésen át a pericardiumba ,pledgetes” dohányzacskóöltéssel kanült (K31 nasogastricus szonda, Laboratori Don Baxter S.p.A, Trieszt, Olaszország) rögzítettünk, a vér szivárgását a kanül mellett rendszeresen ellenőriztük (1. ábra). A tamponád során az artériás középnyomást (MAP) 40-45 Hgmm között tartottuk, $100 \pm 50 \mathrm{ml}$ heparinnal alvadásában gátolt saját vér felhasználásával.

\section{Kísérleti protokoll}

Az állatokat véletlenszerúen két csoportra osztottuk. A pericardium feltöltése kivételével az álmütött csoport $(n=6)$ egyedei ugyanazokon a beavatkozásokon estek át, mint a második csoport állatai. A második csoport $(n=6)$ állataiban 60 perces pericardialis tamponádot követöen 180 perc reperfúzió történt, amelynek során 30 percenként hemodinamikai mérések történtek és artériás és vénás vérgázanalízisre mintát vettünk. A kísérletek -5., 30., 60., 90. és 240. percében mieloperoxidáz (MPO) -enzimaktivitás mérésére vérmintákat gyüjtöttünk a neutrophilgranulocyta-aktiváció meghatározására, valamint in vivo szövettani vizsgálatokat végeztünk a kísérlet $0 ., 90$. és 240 . percében.

\section{Hemodinamikai monitorozás}

A centrális vénás nyomást (CVP), az arteria mesenterica superior és az arteria renalis áramlását folyamatosan regisztráltuk számítógépes adatgyüjtő rendszer segítségével (SPELL Haemosys; Experimetria, Budapest, Magyarország). A MAP, CO, szívfrekvencia (HR) értékeit és az ebből számolt egyéb paramétereket a PiCCO Plus intenzív terápiás monitorral (PiCCO Plus, PULSION Medical Systems AG, München, Németország) regisztráltuk.

\section{Mieloperoxidázenzim-aktivitás mérése}

A vena jugularisból 5 ml-nyi vérmintákat vettünk EDTA-t tartalmazó polipropilén csövekbe, majd $1200 \mathrm{G}$-vel $4{ }^{\circ} \mathrm{C}$ on 15 percig centrifugáltuk. A plazmamintákból, amelyeket felhasználásig $-70{ }^{\circ} \mathrm{C}$-on tároltunk, a neutrophilgranulocyta-aktivációt jellemző MPO-enzimaktivitást Kuebler metodikája alapján határoztunk meg. ${ }^{7}$

\section{A szövetkárosodás in vivo vizsgálata}

A terminális ileum nyálkahártya-károsodásának mértékét in vivo szövettani vizsgálómódszerrel, konfokális, pásztázó lézeres endomikroszkóp (CLSEM) segítségével határoztuk meg (Five1, Optiscan Pty. Ltd., Melbourne, Victoria, Ausztrália). A terminális ileum lumenét megnyitottuk, a nyálkahártyát feltártuk. A nyálkahártya szerkezeti változásait akriflavin fluoreszcens festék (Sigma-Aldrich Inc., St. Louis, Missouri, Amerikai Egyesült Államok) felszíni alkalmazása után vizsgáltuk. A felesleges festéket két perccel a képek készítése előtt fiziológiás sóval lemostuk a nyálkahártyáról. Az eszköz objektívét a vékonybél-nyálkahártyára helyeztük és konfokális képeket (1 szken/kép, $1024 \times 512$ pixel és $475 \times 475 \mu$ m képenként) készítettünk a tamponádot megelőzően, és a reperfúzió 30., illetve 210 . percében. A vizsgálatokat követően az állatokat nátrium-pentobarbitállal túlaltattuk $(120 \mathrm{mg} / \mathrm{ttkg} i v$; Pentobarbital sodium salt C-II; Sigma-Aldrich Inc, St. Louis, Missouri, Amerikai Egyesült Államok).

\section{Statisztikai analízis}

Az adatok kiértékelését statisztikai szoftvercsomag segítségével végeztük (SigmaStat for Windows, Jandel Scientific, Németország), nemparametriás módszereket alkalmazva. A csoporton belüli eltéréseket Friedman-próbával vizsgáltuk, ezen belül a kontrollértéktől való eltérést Dunn-próbával teszteltük. A csoportok közötti különbségek meghatározása Mann-Whitney-próbával történt. Ábráinkon a medián értéket és a szórást jellemző 25 . és 75 . percentilist tüntettük fel, a statisztikai szignifikanciaszintet $p<0,05$-nál határoztuk meg. A grafikonokon a medián értéket és a szórás jellemzésére a 25 és 75 percentilis értékeket tüntettük fel.

\section{Eredmények}

\section{Hemodinamikai paraméterek változása}

A mütéti preparálás átlagosan 70 percet $( \pm 20$ perc $)$ vett igénybe. A 60 perces tamponád időszaka alatt a MAP tervezetten 40-45 Hgmm-en maradt, ez idő alatt a CO jelentősen csökkent. A tamponádot követően a $\mathrm{CO}$ a kontrollértékek szintjére emelkedett, nem volt szignifikáns különbség az álmütött csoporthoz képest ( $2 A$. ábra). A MAP a tamponádot követő időszakban egészen a kísérlet végéig szignifikánsan alacsonyabb maradt a kontrollidőszak és az álmütött csoport értékeihez képest is $(2 B$. ábra). A CO normalizálódását kompenzációs folyamatok kísérték, amelyek fontos eleme a HR szignifikáns emelkedése, mind a kontrollértékekhez, mind az álmütött csoporthoz képest (2C. ábra).

A tamponád alatt szignifikánsan emelkedett CVP-t is mértünk, amely a vénás visszaáramlás romlására utal (2D. ábra). Ez a jelenség a Beck-triász részeként, a tam- 

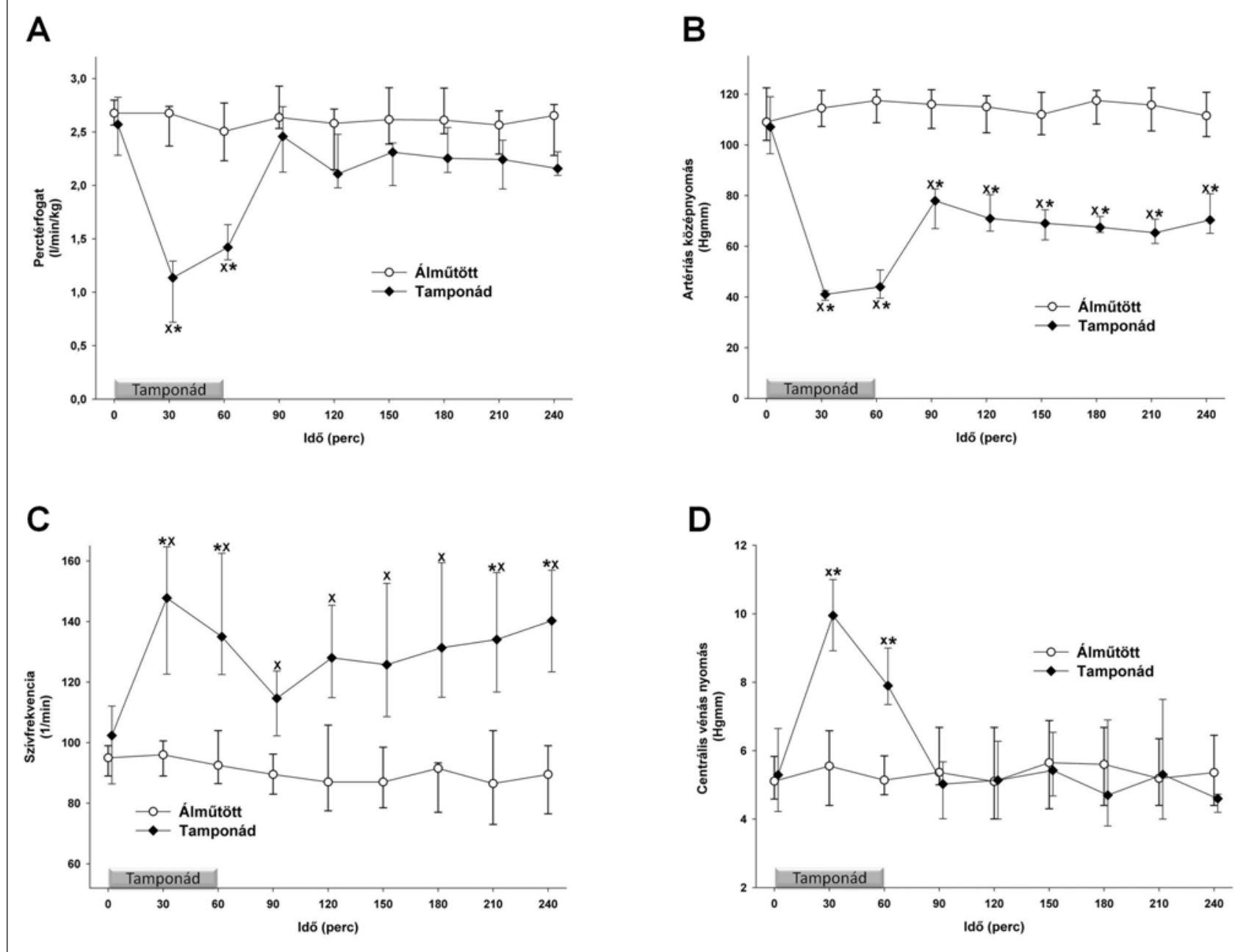

2. ábra. A perctérfogatindex (A), artériás középnyomás (B), szívfrekvencia (C) és a centrális vénás nyomás (D) változásai az álműtött (fehér kör - vékony vonal) és a tamponád (fekete rombusz - vékony vonal) csoportokban. A grafikonon a medián értéket és a szórás jellemzésére a 25 és 75 percentilis értékeket tüntettük fel. ${ }^{*} p<0,05$ csoporton belüli szignifikáns változást mutatja; ${ }^{\mathrm{x}} p<0,05$ a kontrollcsoporthoz képest

ponád fontos jeleként ismert a klinikumban, kitágult, telt nyaki vénákkal jár.

$\mathrm{Az}$ arteria mesenterica superiorban a tamponád alatt a keringés romlását figyelhettük meg, a kísérlet további szakaszában nem mutattunk ki szignifikáns különbséget sem a kontrollértékekhez, sem az álmütött csoporthoz képest (3A. ábra). Az arteria renalis esetében a tamponád alatt az áramlás szignifikánsan csökkent, majd a poszttamponád alatt sem érte el a kontrollértéket ( $3 B$. ábra).

\section{Leukocyta-akkumuláció}

A neutrophilgranulocyta-aktivációt jellemző MPO-enzim aktivitása már a tamponád vége előtt gyüjtött vérmintákban is jelentős emelkedést mutat, majd a tamponádot követő 30. percre éri el a csúcsát. A kísérlet végére azonban a kontrollértékre csökken és az álmütött csoporthoz képest sem lehet különbséget kimutatni (4. ábra). Ez a jelenség a reperfúziós időszak kiemelt fontosságát mutatja a tamponádot követő gyulladás által kiváltott szövődmények kialakulásában.

\section{Szövettani változások}

Valós idejü szövettani vizsgálatokat végeztünk CLSEMtechnikával. Az álmütött állatok bélnyálkahártyája nem károsodott (5A-C-E. ábra) és a kontrollidőszakban a tamponádos csoport állatainak bélnyálkahártyája is ép volt (5B. ábra). A tamponádot követő időszak 30. percében a mucosán már repedések (fehér csillag) és hámhiányok (fehér nyíl) alakultak ki (5D. ábra). Az obszervációs időszak végén készített felvételek számos kiterjedt hámhiányt mutattak (5F. ábra, fehér nyíl).

\section{Összegzés}

A korábbiakban már sikeresen alkalmaztuk a nyitott mellkas mellett kialakított kísérletes pericardialis tamponádot a cardiogen sokk hemodinamikai változásainak tanulmányozására, ${ }^{6,8}$ amely alkalmas a nyitott szívmütétek során kialakuló szövődményes cardiogen sokk modellezésére. Eredményeink és tapasztalataink szerint a most bemutatott 


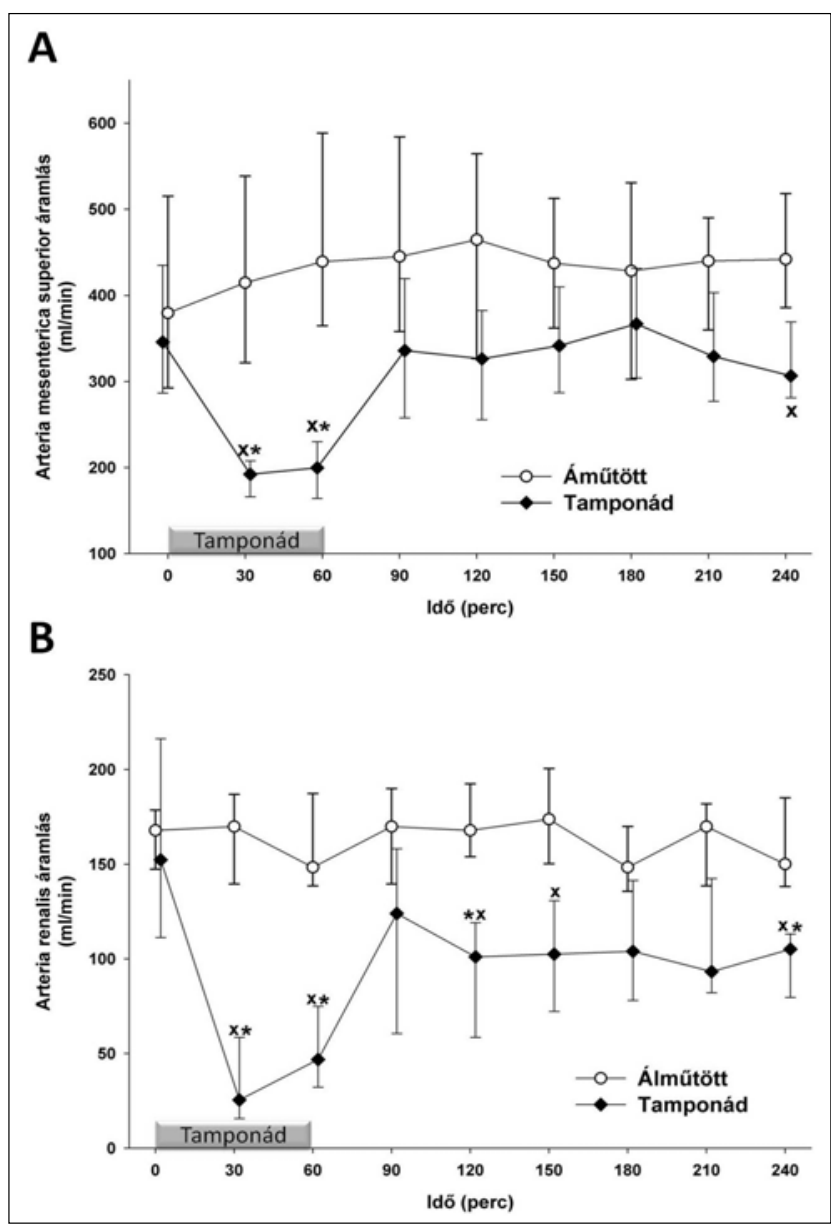

3. ábra. Az arteria mesenterica superior áramlása (A) és az arteria renalis véráramlás $(\mathrm{B})$ változásai az álműtött (fehér kör - vékony vonal) és a tamponád (fekete rombusz - vékony vonal) csoportokban. A grafikonon a medián értéket és a szórás jellemzésére a 25 és 75 percentilis értékeket tüntettük fel. ${ }^{*} p<0,05$ csoporton belüli szignifikáns változást mutatja a kiindulási értékhez képest; ${ }^{\mathrm{x}} p<0,05$ a kontrollcsoporthoz képest

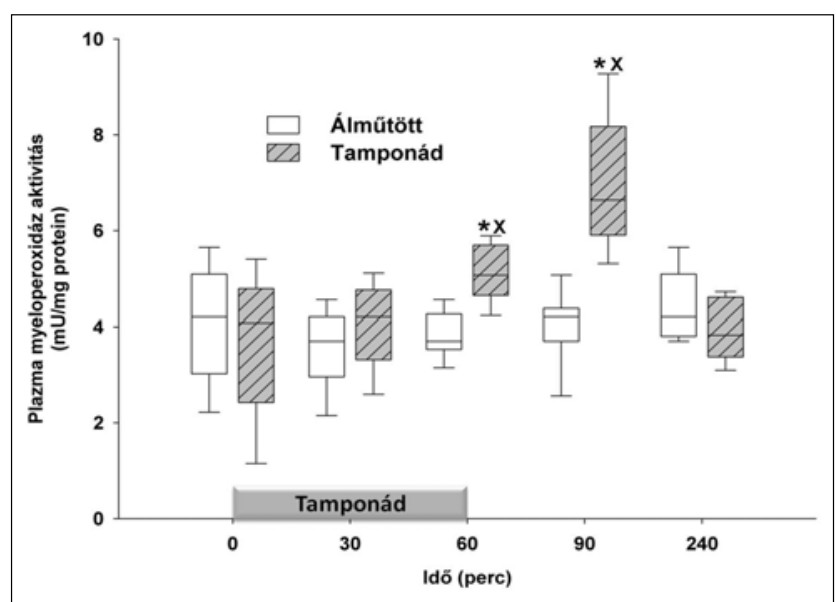

4. ábra. A plazmamieloperoxidázenzim-aktivitás változása az álmütött (fehér box) és a tamponád (szürke, jobbra sávozott box) csoportokban. A grafikonon a medián értéket és a szórás jellemzésére a 25 és 75 percentilis értékeket tüntettük fel. ${ }^{*} p<0,05$ csoporton belüli szignifikáns változást mutatja a kiindulási értékhez képest; ${ }^{\mathrm{x}} p<0,05$ a kontrollcsoporthoz képest
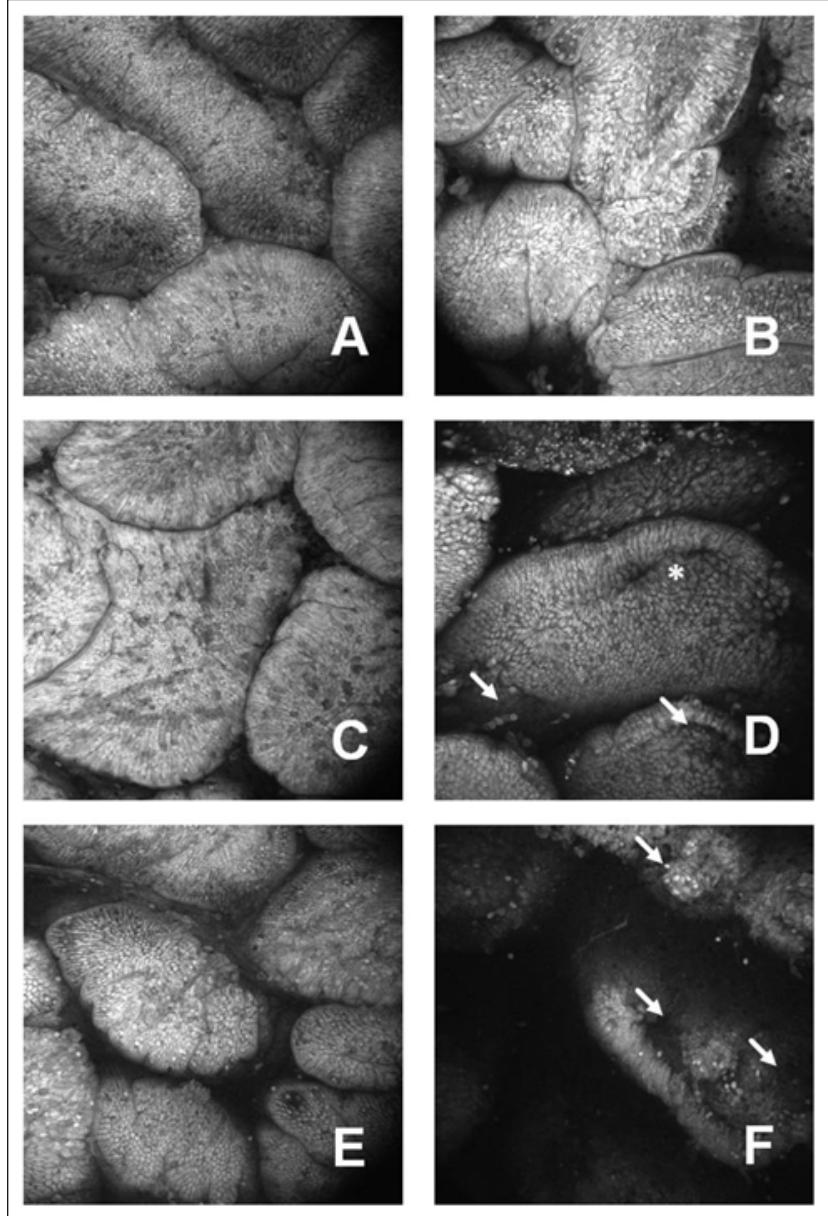

5. ábra. A terminális ileum-nyálkahártya konfokális pásztázó lézeres endomikroszkópos in vivo szövettani felvételei fluoreszcens akriflavin felszíni alkalmazását követően. Az álmütött csoport nyálkahártyafelszíne $(\mathrm{A}, \mathrm{C}, \mathrm{E})$, valamint a tamponádcsoport felszíni nyálkahártya-struktúrája $(\mathrm{B}, \mathrm{D}, \mathrm{F})$

kísérletes protokoll jól használható az alacsony perctérfogattal járó keringési sokk akut és szubakut kórélettani következményeinek vizsgálatára és jól tükrözi az NCSP alatt kialakuló cardiogen sokk tüneteit.

A szívburok megnövekedett nyomása elöször az alacsony nyomású erekre és szívüregekre, így a vena cava superiorra és inferiorra, valamint a jobb pitvarra van hatással. A szívciklus során a pitvarokban és a kamrákban a nyomások dinamikusan változnak, amelyek során a pericardialis nyomás a jobb pitvar telődését, és következményesen a jobb kamra diasztolés telödését gátolja. A cardiogen sokk kialakulásával számos kompenzációs mechanizmus aktiválódik, amelynek során a szervezet az életfontosságú szervek perfúziójának fenntartására törekszik. A szívizom kontraktilitásának növekedése mellett a szívfrekvencia nő, amely a CO fenntartásához szükséges. Ezenfelül a szervezetben inhomogén módon volumenredisztribúció történik szisztémás és helyi vazoaktív válaszokkal, így például a vázizomzat, a bőr és a mesenterium ereiben jelentős vasoconstrictio történik., ${ }^{3,9-11}$.

A szívsebészeti intenzív betegellátás során megfigyelhető alacsony óradiuresis a pericardialis folyadékfelszapo- 
rodás, a fenyegető pericardialis tamponád első jele. Kísérleteink során igazoltuk, hogy az arteria renalis áramlása a tamponádot követően, a rendeződő CO mellett is jelentősen alacsonyabb a kontrollértékekhez képest. A vesék romló müködése a klinikumban jól ismert, jelentős problémát jelent. A vesefunkció javítására irányuló kezelési lehetőségek kísérletes vizsgálatára az általunk kialakított új sertéstamponád-modell fontos eszköz lehet, e folyamatok kiterjedt invazív hemodinamikai monitorozására nyílhat lehetőség. A thoracotomia hiánya egyszerübb, gyorsabb és kevesebb traumával járó mütéti kivitelezést jelentett, anélkül, hogy a hemodinamikai és biokémiai mérések pontossága megváltozna. A pericardium feltöltésére saját, heparinnal alvadásában gátolt vért használtunk, s itt meg kell jegyezni, hogy az eddig e célra alkalmazott kolloid oldatok esetén több folyadékra van szükség azonos MAP-mértékü MAP-csökkenés eléréséhez, továbbá, hogy nem észleltük folyadék (vér) szivárgását a vékony pericardiumon keresztül, ezáltal a megválasztott, tamponád alatti MAP-célérték pontosan beállítható és tartható. A transphrenicus behatoláson át kialakított tamponád további jelentős előnye, hogy a laparotomia zárását követően lehetővé teheti sikeres, túlélő kísérletek során a krónikus változásokkal kapcsolatos adatok gyüjtését is.

Összefoglalásként tehát elmondható, hogy pericardialistamponád-modellünk jól tükrözi a klinikai képre jellemző hemodinamikai és gyulladásos változásokat, alkalmas a lokális, az egyes szerveket érintő keringési változások vizsgálatára is. A mellkasba történő behatolás új, transphrenicus módja alacsonyabb megterhelést jelent az állatok számára, új kísérleti protokollok tervezését és a vizsgálati időtartamok kiterjesztését teszi lehetővé.

Támogatás: NKFI-116861, GINOP-2.3.2-15-2016-00015, EFOP-3.6.2-16-2017-00006

\section{Irodalomjegyzék}

${ }^{1}$ Orbach A, Schliamser JE, Flugelman MY, Zafrir B. Contemporary evaluation of the causes of cardiac tamponade: Acute and long-term outcomes. Cardiol J 2016; 23(1): 57-63

${ }^{2}$ Bodson L, Bouferrache K, Vieillard-Baron A. Cardiac tamponade: Curr Opin Crit Care 2011; 17(5): 416-424

${ }^{3}$ Carmona P, Mateo E, Casanovas I, et al. Management of cardiac tamponade after cardiac surgery. J Cardiothorac Vasc Anesth 2012; 26(2): 302-311

${ }^{4}$ Rivera-Nieves J, Gorfu G, Ley K. Leukocyte adhesion molecules in animal models of inflammatory bowel disease: Inflamm Bowel Dis 2008; 14(12): 1715-1735

${ }^{5}$ Osuchowski MF, Remick DG, Lederer JA, et al. Abandon the mouse research ship? Not just yet!: Shock 2014; 41(6): 463-475

${ }^{6}$ Kaszaki J, Nagy S, Tárnoky K, et al. Humoral changes in shock induced by cardiac tamponade. Circ Shock 1989; 29(2): 143-153

${ }^{7}$ Kuebler WM, Abels C, Schuerer L, et al. Measurement of neutrophil content in brain and lung tissue by a modified myeloperoxidase assay. Int J Microcirc 1996; 16: 89-97

${ }^{8}$ Érces D, Nógrády $M$, Nagy E, et al. Complement C5A antagonist treatment improves the acute circulatory and inflammatory consequences of experimental cardiac tamponade: Crit Care Med 2013; 41(11): e344-e351

9 Spodick $D H$. Acute cardiac tamponade. N Engl J Med 2003; 349(7): 684-690

${ }^{10}$ Ashikhmina EA, Schaff HV, Sinak LJ, et al. Pericardial effusion after cardiac surgery: risk factors, patient profiles, and contemporary management. Ann Thorac Surg 2010; 89(1): 112-118

${ }^{11}$ Kuvin JT, Harati NA, Pandian NG, Bojar RM, Khabbaz $K R$. Postoperative cardiac tamponade in the modern surgical era. Ann Thorac Surg 2002; 74(4): 1148-1153 